University of Nebraska - Lincoln

DigitalCommons@University of Nebraska - Lincoln

Virology Papers

Virology, Nebraska Center for

2002

Characterization of CD4-Induced Epitopes on the HIV Type 1

gp120 Envelope Glycoprotein Recognized by Neutralizing Human

Monoclonal Antibodies

\author{
Shi-Hua Xiang \\ University of Nebraska-Lincoln, sxiang2@unl.edu \\ Najah Doka \\ Harvard Medical School \\ Rabeéa K. Choudhary \\ Harvard Medical School \\ Joseph Sodroski \\ Harvard Medical School, fdajiop@gmail.com \\ James E. Robinson \\ Tulane University Medical Center
}

Follow this and additional works at: https://digitalcommons.unl.edu/virologypub

Part of the Virology Commons

Xiang, Shi-Hua; Doka, Najah; Choudhary, Rabeéa K.; Sodroski, Joseph; and Robinson, James E., "Characterization of CD4-Induced Epitopes on the HIV Type $1 \mathrm{gp} 120$ Envelope Glycoprotein Recognized by Neutralizing Human Monoclonal Antibodies" (2002). Virology Papers. 199.

https://digitalcommons.unl.edu/virologypub/199

This Article is brought to you for free and open access by the Virology, Nebraska Center for at DigitalCommons@University of Nebraska - Lincoln. It has been accepted for inclusion in Virology Papers by an authorized administrator of DigitalCommons@University of Nebraska - Lincoln. 


\title{
Characterization of CD4-Induced Epitopes on the HIV Type 1 gp120 Envelope Glycoprotein Recognized by Neutralizing Human Monoclonal Antibodies
}

\author{
SHI-HUA XIANG,${ }^{1,2}$ NAJAH DOKA,${ }^{1}$ RABEÉA K. CHOUDHARY,${ }^{1}$ JOSEPH SODROSKI,,${ }^{1,2,3}$ and \\ JAMES E. ROBINSON ${ }^{4}$
}

\begin{abstract}
The entry of human immunodeficiency virus (HIV-1) into target cells typically requires the sequential binding of the viral exterior envelope glycoprotein, gp120, to CD4 and a chemokine receptor. CD4 binding exposes gp120 epitopes recognized by CD4-induced (CD4i) antibodies, which can block virus binding to the chemokine receptor. We identified three new CD4i antibodies from an HIV-1-infected individual and localized their epitopes. These epitopes include a highly conserved gp120 $\beta$-strand encompassing residues 419-424, which is also important for binding to the CCR5 chemokine receptor. All of the CD4i antibodies inhibited the binding of gp120-CD4 complexes to CCR5. CD4i antibodies and CD4 reciprocally induced each other's binding, suggesting that these ligands recognize a similar gp120 conformation. The CD4i antibodies neutralized laboratory-adapted HIV-1 isolates; primary isolates were more resistant to neutralization by these antibodies. Thus, all known CD4i antibodies recognize a common, conserved gp120 element overlapping the binding site for the CCR5 chemokine receptor.
\end{abstract}

\section{INTRODUCTION}

$\mathbf{H}$ UMAN IMMUNODEFICIENCY VIRUS (HIV-1) is the major cause of acquired immunodeficiency syndrome (AIDS) in humans. ${ }^{1,2}$ AIDS results from a progressive loss of CD4 ${ }^{+}$T-lymphocytes that accompanies chronic HIV-1 infection. ${ }^{3-8}$ The $\mathrm{CD}^{+} \mathrm{T}$ lymphocytes represent major target cells for HIV-1, and this tropism is determined by specific interactions of the viral envelope glycoproteins and host cell receptors, CD4 and members of the chemokine receptor family. ${ }^{9-11}$ Receptor binding is mediated by the gp120 exterior envelope glycoprotein, ${ }^{9-11}$ which is organized into a trimeric complex along with the gp41 transmembrane envelope glycoprotein. ${ }^{12,13}$ The binding of gp120 to CD4 induces conformational changes that allow gp120 to interact with the chemokine receptors, CCR5 or CXCR4. ${ }^{10,14-18}$ One of these CD4-induced conformational changes is a shift in the position of the large, surface-exposed V1/V2 variable loops of gp120, which are thought to mask the chemokine receptor-binding site on gp $120 .{ }^{19-22}$ Chemokine re- ceptor binding apparently involves a conserved structure on the gp120 surface and sequences in the third variable (V3) loop. ${ }^{9-11,23-27}$ The conserved gp120 structures involved in receptor binding have been defined by X-ray crystallographic analysis of HIV-1 gp120 core elements, mutagenesis, and antibody competition analyses. ${ }^{21,23,24,28-30}$ Receptor binding is believed to trigger additional conformational changes in the HIV-1 envelope glycoproteins that lead to exposure of the gp41 transmembrane envelope glycoprotein and to gp41-mediated fusion of the viral and target cell membranes. ${ }^{31,32}$

The persistence of HIV-1 infection and eventual disease induction in most infected hosts imply that the virus can evade and, ultimately, eliminate the immune response. ${ }^{33,34}$ The HIV1 envelope glycoproteins possess surface-exposedloops that exhibit considerable variation among strains. A high degree of glycosylation and conformational flexibility are other features that are thought to minimize the elicitation or effect of neutralizing antibodies. ${ }^{21,35}$ Many antibodies elicited by the HIV1 envelope glycoproteins do not exhibit the ability to neutral-

\footnotetext{
${ }^{1}$ Department of Cancer Immunology and AIDS, Dana-Farber Cancer Institute, ${ }^{2}$ Department of Pathology, Division of AIDS, Harvard Medical School, and ${ }^{3}$ Department of Immunology and Infectious Diseases, Harvard School of Public Health, Boston, Massachusetts 02115.

${ }^{4}$ Department of Pediatrics, Tulane University Medical Center, New Orleans, Louisiana 70012.
} 
ize the virus. Neutralizing antibodies elicited relatively early in the course of natural infection often inhibit the infection of a limited number of viral strains, and typically are directed against variable loops. Later-arising antibodies exhibit broader neutralizing activity against HIV-1 strains. These antibodies include CD4-binding-site (CD4BS) antibodies, which block CD4 binding, and CD4-induced (CD4i) antibodies, which recognize gp120 structures that are formed or exposed by CD4 binding. The CD4i antibodies block the binding of HIV-1 gp120 to the chemokine receptors. To date, only two HIV-1-specific CD4i antibodies, designated $17 \mathrm{~b}$ and $48 \mathrm{~d}$, have been identified and studied. ${ }^{22,36-38}$ The binding of these antibodies to HIV-1 gp120 can be disrupted by changes in the bridging sheet, a highly conserved gp120 element implicated in chemokine receptor binding. X-ray crystal structures of two HIV-1 gp120 cores complexed with CD4 and Fab fragments of the 17b antibody have been determined, allowing precise definition of the $17 \mathrm{~b}$ epitope. ${ }^{28,29}$ The epitopes for the $17 \mathrm{~b}$ and $48 \mathrm{~d}$ antibodies are thought to be partially masked by the second variable (V2) loop of gp120, and virus variants lacking the V1/V2 or V2 loops exhibit greater sensitivity to neutralization by these antibodies. ${ }^{20,22,39,40}$ The gp120 variable loop conformations on many primary HIV-1 isolates apparently mask the $17 \mathrm{~b}$ and $48 \mathrm{~d}$ epitopes quite effectively, because these viruses are relatively resistant to $17 \mathrm{~b}$ and $48 \mathrm{~d}$ neutralization..$^{21,22,38,41-44}$ Steric factors dictate that to neutralize HIV-1 effectively, these antibodies must bind the viral envelope glycoproteins prior to the engagement of the CD4 receptor on the target cell. ${ }^{20}$ Thus, although the conservation of these antibody epitopes is an attractive feature, HIV-1 has evolved mechanisms to diminish their accessibility to antibodies.

To obtain further understanding of gp120 epitopes induced by CD4 binding, we identified three new CD4i antibodies $(23 \mathrm{e}$, 21c, and 49e) from HIV-1-infected individuals. We characterized their binding to wild-type and mutant gp120 glycoproteins, the influence of CD4 binding on their interaction with gp120, and their neutralizing ability.

\section{MATERIALS AND METHODS}

\section{Cells}

293 T cells were cultured in Dulbecco's modified Eagle's medium (DMEM) with 10\% fetal bovine serum (FBS) and penicillin/streptomycin. CCR5 binding assays utilized Cf2ThsynCCR5 cells. ${ }^{12}$ To study the entry of R5 viruses, Cf2Th cells expressing CD4 and CCR5 were used. To study the entry of $\mathrm{X} 4$ isolates, Ghost cells expressing CD4 and CXCR4 were used.

\section{Mutant HIV-1 gp120 glycoproteins}

Single amino acid changes were introduced into the wt $\Delta$ protein from the YU2 isolate, a primary R5 HIV-1 derived directly from the brain of an infected individual. The wt $\Delta$ protein contains deletions of gp120 residues 31-81 in the N-terminus and 128-194, removing the V1 and V2 variable loops but retaining the conserved V1/V2 stem. (Numbering of gp120 amino acid residues is based on the sequence of the prototypic $\mathrm{HXBc} 2$ strain of HIV-1, according to current convention..$^{45}$ )

\section{Antibodies}

The human monoclonal antibodies (HMAbs) 17b, 23e, 49e, 21c, and 48d were derived by Epstein-Barr virus (EBV) transformation of $\mathrm{B}$ cells from cryopreserved peripheral blood mononuclear cells (PBMC) obtained from HIV-1-infected individuals. The $23 \mathrm{e}, 49 \mathrm{e}$, and $21 \mathrm{c}$ monoclonal antibody-producing cell lines were obtained from an HIV-1 infected long-term nonprogressor (AD19) followed at the Aaron Diamond AIDS Research Center. EBV-inoculated PBMC cultures were plated in multiple 96-well culture plates containing irradiated, mature human macrophages as feeder cells, as previously described. ${ }^{46,47} \mathrm{Su}-$ pernatant fluids from transformed cultures were screened for antibodies binding to HIV-1 envelope glycoproteins using a "reverse capture" sandwich immunoassay, according to our published method. ${ }^{46}$ Briefly, potential HMAbs in B cell culture fluids were first captured in wells of ELISA plates coated with $2 \mu \mathrm{g} / \mathrm{ml}$ goat anti-human IgG-Fc. Detergent-solubilized virus containing 10\% normal human serum (Irvine Scientific) was incubated in the wells to allow binding of viral antigens to immobilized antibodies. Detection of bound viral envelope glycoproteins was accomplished by addition of a mixture of several biotinylated HMAbs $(17 \mathrm{~b}$, A32, C11), also diluted in buffer containing 10\% human serum, which recognize nonoverlapping, well-conserved sites on HIV-1 gp120. In the present experiments we screened for antibodies binding to a mixture of HIV-1 strains (IIIB and J62). ${ }^{47}$ Antigen stocks consisted of supernatant fluids of cultures of MT4 cells chronically infected with each virus. Culture fluids were collected once weekly, clarified by centrifugation, and treated with $1 \%$ Triton-X100 to inactivate virus infectivity and solubilize the glycoproteins. We used several noncompeting, biotin-labeled HMAbs to make sure that if the captured HMAb competed for the binding site of one labeled HMAb, one of the other labeled HMAbs would still detect bound gp120. Normal human serum (10\%) was added to the dilution buffer in both the virus and biotin-HMAb steps to saturate all anti-IgG-Fc binding sites, thus preventing binding of the biotinylated antibodies, which otherwise would cause unacceptably high background signals. Microwell cultures that contained antibody-producing cells were subcultured at low cell densities and rescreened for antibody production. Stable antibody-producing cell lines were finally cloned at limiting dilutions. To improve cell growth and antibody production, the cell lines producing $23 \mathrm{e}$ and $21 \mathrm{c} \mathrm{HMAbs} \mathrm{subsequentlywere} \mathrm{converted}$ to hybridomas by fusion with HMMA cells, kindly provided by Marshall Posner. HMAbs were purified from several liters of culture supernatant using protein A affinity chromatography. Protein concentration was determined by the bicinchinonic acid (BCA) method (Pierce Chemical Co.).

\section{Antibody binding competition assays}

To test the effect of soluble CD4 (sCD4) on HMAb binding, the wild-type YU2 gp120 glycoprotein was captured on an ELISA plate by the D7324 antibody (Aalto BioReagents, Dublin, Ireland) which is directed against the HIV-1 gp120 Cterminus. ${ }^{30}$ HMAbs were added to the wells for $1 \mathrm{hr}$ in the absence or presence of $10 \mu \mathrm{g} / \mathrm{ml} \mathrm{sCD} 4$. After washing, the bound antibody was detected with horseradish peroxidase-conjugated anti-human IgG antibody (Sigma).

To test the ability of the HMAbs to compete with the $17 \mathrm{~b}$ antibody for gp120 binding, the 17b HMAb was biotinylated 

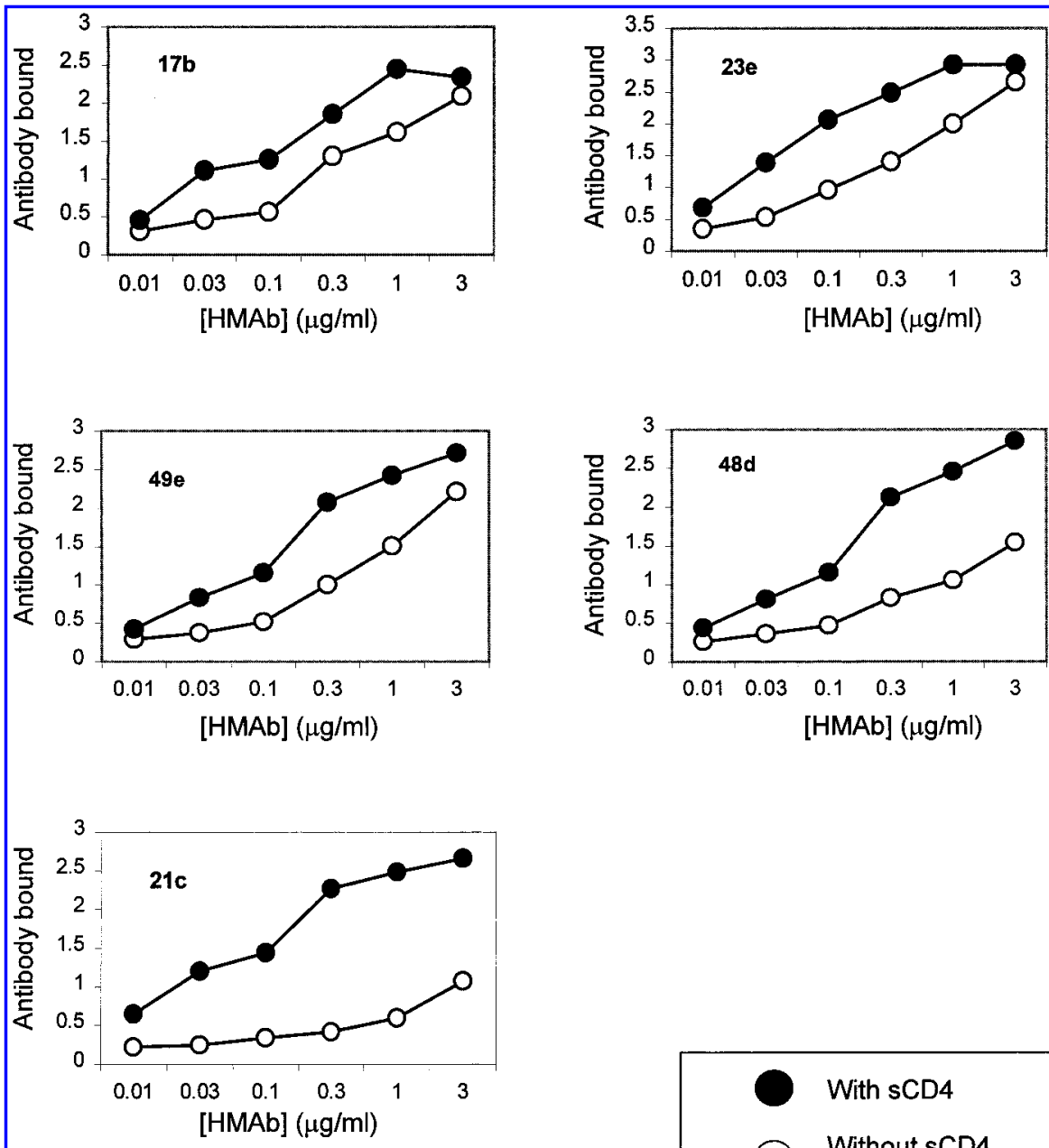

With $\mathrm{SCD} 4$

Without SCD4

FIG. 1. Effects of sCD4 on HMAb binding to HIV-1 gp120. The gp120 glycoprotein from the YU2 HIV-1 isolate was captured on ELISA plates by the D7324 antibody. The captured gp120 glycoprotein was incubated without sCD4 (open circles) or with $10 \mu \mathrm{g} / \mathrm{ml} \mathrm{sCD} 4$ (filled circles), together with the HMAbs 17b, 23e, 49e, 21c, and 48d. The bound antibody was detected as described under Materials and Methods. The amount of antibody bound is expressed in optical density units.

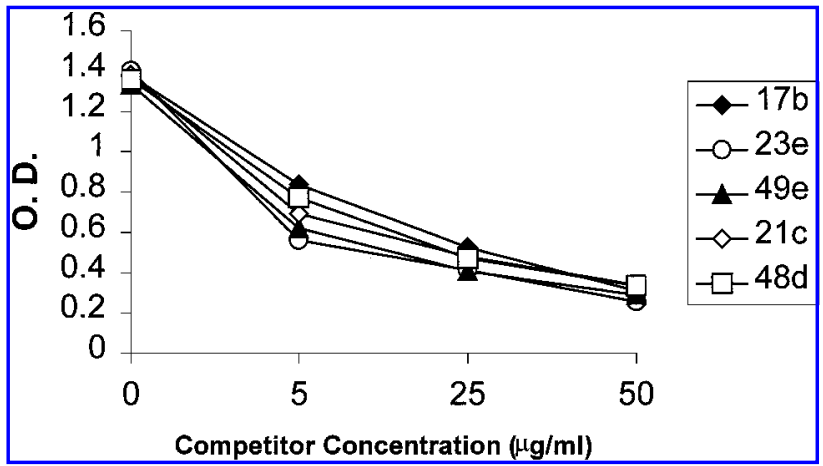

FIG. 2. Ability of CD4i HMAbs to compete with $17 \mathrm{~b}$ antibody for gp120. The HIV-1 gp120 glycoprotein was captured on ELISA plates with the D7324 antibody. The binding of biotinylated $17 \mathrm{~b}$ antibody to the gp120 glycoprotein in the presence of the indicated concentrations of competitor HMAbs was detected by avidin-peroxidase as described under Materials and Methods. using EZ-link sulfo-NHS-LC-biotin (Pierce) according to the manufacturer's instructions. Ninety-six-wellELISA plates were coated with the sheep D7324 antibody (Aalto BioReagents, Dublin, Ireland), which is directed against the extreme C-terminus of HIV-1 gp120..$^{30}$ The wt $\Delta$ gp120 protein of the YU2 HIV-1 strain was produced by transient expression of $293 \mathrm{~T}$ cells and added to the D7324 antibody-coated wells. A dose-response curve was generated for $17 \mathrm{~b}$-biotin, and a concentration of $0.5 \mu \mathrm{g} / \mathrm{ml} \mathrm{17b-biotin} \mathrm{was} \mathrm{chosen} \mathrm{because} \mathrm{this} \mathrm{concentration}$ was not saturating, yet yielded a robust signal in the assay. For the competition assay, various concentrations of the competitor antibody were first mixed with the $17 \mathrm{~b}$-biotin $(0.5 \mu \mathrm{g} / \mathrm{ml})$ and then added to the wells containing the captured gp120 glycoproteins. The $17 \mathrm{~b}$ antibody itself and the $2 / 11 \mathrm{c}$ antibody were used as positive and negative competitor controls, respectively. The bound 17b-biotin was detected with avidin-peroxidaseconjugate (Sigma), and the assays were developed with the TMB peroxidase EIA substrate (BioRad). 


\section{CCR5 binding assay}

To examine whether the HMAbs competed with the ability of gp120 to bind CCR5, $100 \mu \mathrm{l}$ of ${ }^{35}$ S-labeled gp120 was incubated with approximately $5 \times 10^{6} \mathrm{Cf} 2 \mathrm{ThsynCCR} 5$ cells $^{12}$ and with various concentrations of HMAbs in the presence of soluble CD4 $(5 \mu \mathrm{g} / \mathrm{ml})$. After $1.5 \mathrm{hr}$ incubation at room tempera- ture, the cells were pelleted ( $3000 \mathrm{rpm}$ for $2 \mathrm{~min}$ ), washed with phosphate-bufferedsaline (PBS), and lysed in NP-40 buffer. The lysates were centrifuged at $14,000 \mathrm{rpm}$ at $4^{\circ} \mathrm{C}$ for $5 \mathrm{~min}$ to remove cell debris. The supernatants containing the bound envelope glycoproteins were precipitated by a mixture of sera from HIV-1-infected individuals and resolved by sodium dodecyl sulfate-polyacrylamide gel electrophoresis (SDS-PAGE).

Table 1. Recognition of HIV-1 gp120 Mutants by Ligands ${ }^{\text {a }}$

\begin{tabular}{|c|c|c|c|c|c|c|c|c|c|}
\hline gp120 region & Envelope protein & $s C D 4$ & Serum & $17 b$ & $23 e$ & $49 e$ & $21 c$ & $48 d$ & CCR5 \\
\hline & YU2 wt $\Delta$ & 1.00 & 1.00 & 1.00 & 1.00 & 1.00 & 1.00 & 1.00 & 1.00 \\
\hline \multirow[t]{6}{*}{$\mathrm{C} 1$} & $107 \mathrm{D} / \mathrm{R}$ & 1.02 & 0.98 & 0.97 & 0.73 & 0.94 & 0.65 & 0.85 & 1.02 \\
\hline & $114 \mathrm{Q} / \mathrm{L}$ & 0.79 & 0.60 & 0.73 & 1.08 & 1.34 & 0.79 & 0.97 & 1.22 \\
\hline & $117 \mathrm{~K} / \mathrm{D}$ & 0.74 & 0.75 & $0.40(+)$ & $0.29(+)$ & $0.02(-)$ & $0.30(+)$ & $0.00(+)$ & 0.15 \\
\hline & $121 \mathrm{~K} / \mathrm{D}$ & 0.73 & 1.15 & $0.00(+)$ & $0.17(+)$ & $0.00(+)$ & $0.10(+)$ & $0.00(-)$ & 0.07 \\
\hline & $122 \mathrm{~L} / \mathrm{S}$ & 0.84 & 1.80 & 1.07 & 1.08 & 0.97 & 0.94 & $0.08(+)$ & 0.98 \\
\hline & $123 \mathrm{~T} / \mathrm{D}$ & 0.99 & 0.70 & 1.06 & 0.89 & 0.56 & 1.06 & $0.00(-)$ & 0.08 \\
\hline \multirow[t]{10}{*}{$\mathrm{C} 2$} & 197 N/D & 1.34 & 1.01 & 0.80 & 0.83 & 1.40 & 0.97 & 1.75 & 1.33 \\
\hline & $199 \mathrm{~S} / \mathrm{L}$ & 1.32 & 0.95 & 0.94 & 0.44 & 0.92 & 1.40 & 2.00 & 1.50 \\
\hline & $200 \mathrm{~V} / \mathrm{S}$ & 0.91 & 0.94 & 1.05 & 1.57 & 0.96 & 0.43 & $0.00(+)$ & 0.84 \\
\hline & $201 \mathrm{I} / \mathrm{A}$ & 0.90 & 1.28 & 0.67 & 1.13 & 1.40 & 0.73 & $0.02(+)$ & 0.46 \\
\hline & $203 \mathrm{Q} / \mathrm{L}$ & 0.85 & 1.18 & 0.88 & 0.97 & 0.73 & 0.73 & $0.01(+)$ & 0.68 \\
\hline & $207 \mathrm{~K} / \mathrm{D}$ & 0.85 & 1.03 & $0.10(+)$ & 1.20 & $0.00(-)$ & 0.68 & $0.01(-)$ & 0.00 \\
\hline & $209 \mathrm{~S} / \mathrm{L}$ & 1.11 & 0.87 & 0.85 & 0.89 & 0.67 & 0.81 & 0.92 & 1.00 \\
\hline & $210 \mathrm{~F} / \mathrm{S}$ & 0.81 & 1.36 & 0.81 & 0.81 & 1.45 & 1.24 & 1.22 & 0.65 \\
\hline & $211 \mathrm{E} / \mathrm{K}$ & 1.13 & 1.44 & 1.03 & 1.07 & 1.37 & 1.52 & 0.79 & 0.73 \\
\hline & $257 \mathrm{~T} / \mathrm{D}$ & 0.00 & 0.38 & $0.80(+)$ & $0.18(+)$ & $0.01(+)$ & $0.05(+)$ & $0.00(+)$ & 0.05 \\
\hline \multirow[t]{5}{*}{ V3 } & $295 \mathrm{~N} / \mathrm{E}$ & 0.75 & 1.29 & 0.73 & 0.64 & 1.18 & 1.28 & 1.39 & 0.86 \\
\hline & 308 N/D & 1.10 & 1.63 & 0.89 & 0.55 & 1.32 & 0.69 & 1.21 & 0.31 \\
\hline & $311 \mathrm{~L} / \mathrm{S}$ & 1.12 & 1.02 & 1.05 & 1.09 & 1.40 & 1.08 & 1.93 & 0.08 \\
\hline & $330 \mathrm{H} / \mathrm{A}$ & 0.75 & 1.01 & 0.55 & 0.88 & 0.81 & 0.60 & 1.05 & 0.22 \\
\hline & $\Delta$ V3 $(\Delta 298-329)$ & 0.80 & 1.45 & $0.00(+)$ & $0.00(+)$ & $0.00(+)$ & $0.00(+)$ & $0.00(+)$ & 0.00 \\
\hline \multirow[t]{7}{*}{ C3 } & $370 \mathrm{E} / \mathrm{Q}$ & 0.00 & 0.66 & 1.04 & 1.54 & 1.04 & 0.83 & $0.00(+)$ & 0.17 \\
\hline & $372 \mathrm{~V} / \mathrm{S}$ & 1.03 & 1.14 & 1.08 & 1.02 & 0.67 & 0.77 & 0.96 & 0.85 \\
\hline & $373 \mathrm{~T} / \mathrm{D}$ & 1.12 & 0.77 & 1.10 & 1.34 & 1.43 & 1.19 & 0.71 & 0.48 \\
\hline & 377 N/E & 0.71 & 1.00 & 0.52 & 0.55 & 0.46 & 2.00 & 1.83 & 0.22 \\
\hline & $381 \mathrm{E} / \mathrm{R}$ & 0.81 & 1.27 & $0.20(+)$ & 1.15 & $0.09(-)$ & 1.50 & $0.00(-)$ & 0.07 \\
\hline & $383 \mathrm{~F} / \mathrm{S}$ & 0.00 & 0.49 & $0.02(+)$ & $0.04(+)$ & $0.00(+)$ & $0.00(+)$ & $0.00(+)$ & 0.04 \\
\hline & 386 N/D & 1.14 & 1.83 & 0.97 & 1.62 & 1.18 & 1.32 & 1.04 & 1.22 \\
\hline \multirow[t]{19}{*}{$\mathrm{C} 4$} & 419 R/D & 0.86 & 1.12 & $0.00(+)$ & 1.48 & 0.98 & 1.60 & $0.00(-)$ & 0.19 \\
\hline & $420 \mathrm{I} / \mathrm{R}$ & 0.59 & 0.92 & $0.00(-)$ & $0.00(-)$ & $0.00(-)$ & $0.10(-)$ & $0.00(-)$ & 0.06 \\
\hline & $421 \mathrm{~K} / \mathrm{D}$ & 0.86 & 0.56 & $0.00(+)$ & 1.41 & 0.86 & 1.00 & $0.00(-)$ & 0.07 \\
\hline & $422 \mathrm{Q} / \mathrm{L}$ & 0.53 & 0.80 & $0.00(-)$ & $0.03(+)$ & $0.47(+)$ & $0.00(-)$ & $0.00(-)$ & 0.07 \\
\hline & $423 \mathrm{I} / \mathrm{S}$ & 0.97 & 1.05 & $0.00(-)$ & 1.20 & 1.11 & 0.88 & $0.00(-)$ & 0.61 \\
\hline & $424 \mathrm{I} / \mathrm{S}$ & 0.25 & 0.58 & $0.48(+)$ & $0.15(+)$ & $0.04(+)$ & $0.25(+)$ & $0.00(+)$ & 0.37 \\
\hline & $426 \mathrm{M} / \mathrm{A}$ & 0.69 & 0.85 & 0.69 & 0.74 & 0.58 & 0.30 & $0.08(+)$ & 0.75 \\
\hline & $429 \mathrm{E} / \mathrm{R}$ & 1.17 & 1.04 & 1.00 & 1.11 & 0.68 & 0.70 & 1.75 & 1.54 \\
\hline & $432 \mathrm{~K} / \mathrm{A}$ & 1.00 & 0.52 & 0.92 & 0.81 & 1.00 & 1.02 & $0.00(+)$ & 0.06 \\
\hline & $434 \mathrm{M} / \mathrm{A}$ & 0.90 & 1.31 & 0.65 & 0.77 & 0.63 & 1.00 & $0.00(-)$ & 1.22 \\
\hline & $435 \mathrm{Y} / \mathrm{S}$ & 0.33 & 0.85 & $0.00(+)$ & $0.13(+)$ & $0.00(+)$ & $0.00(+)$ & $0.00(+)$ & 0.21 \\
\hline & $436 \mathrm{~A} / \mathrm{S}$ & 1.05 & 0.97 & 0.91 & 1.03 & 1.09 & 0.93 & 1.73 & 0.98 \\
\hline & 437 P/A & 0.80 & 1.42 & 0.68 & 0.59 & 0.79 & 0.53 & $0.00(-)$ & 1.79 \\
\hline & $438 \mathrm{P} / \mathrm{A}$ & 1.18 & 0.74 & 1.00 & 1.08 & 0.79 & 0.89 & $0.10(+)$ & 0.06 \\
\hline & $439 \mathrm{I} / \mathrm{A}$ & 0.68 & 1.04 & 0.76 & 0.92 & 1.00 & 1.33 & 1.28 & 0.45 \\
\hline & $440 \mathrm{R} / \mathrm{D}$ & 1.03 & 0.99 & 1.05 & 0.94 & 1.04 & 1.45 & $0.02(+)$ & 0.09 \\
\hline & $441 \mathrm{G} / \mathrm{V}$ & 0.67 & 1.10 & 0.70 & 0.96 & 0.77 & 1.43 & $0.02(+)$ & 0.00 \\
\hline & $442 \mathrm{Q} / \mathrm{L}$ & 1.11 & 0.74 & 0.74 & 1.03 & 1.38 & 0.70 & 1.54 & 2.00 \\
\hline & $444 \mathrm{R} / \mathrm{D}$ & 0.79 & 1.04 & 0.67 & 1.26 & 1.18 & 0.75 & 0.40 & 0.25 \\
\hline $\mathrm{C} 5$ & $474 \mathrm{D} / \mathrm{R}$ & 0.59 & 1.02 & 0.81 & 1.09 & 1.34 & 0.72 & 0.52 & 1.03 \\
\hline
\end{tabular}

${ }^{\text {a }}$ The residue number of the mutants is based on sequence of the prototype strain HXBc2. ${ }^{45}$ The value for ligand binding was determined by immunoprecipitation of radiolabeled protein and quantified by a Phosphorlmager. The values were normalized by the formula as follows: (mutant protein/wt protein) ligand $\times$ (wt protein/mutant protein) serum mixture. Values for sCD4, CCR5, and $17 \mathrm{~b}$ binding are from Rizzuto et al. ${ }^{24}+$ indicates that ligand binding is restored to near-wild-type levels by incubation with sCD4. 
Transient expression of HIV-1 envelope glycoprotein variants

293T cells grown to $70 \%$ confluency in $100-\mathrm{mm}$ dishes were transfected with $2 \mu \mathrm{g}$ of a plasmid expressing the wt $\Delta$ protein or mutant derivatives thereof, and $1 \mu \mathrm{g}$ of a plasmid express- ing the HIV-1 Tat protein, using the Effectene Transfection Reagent (QIAGEN). Forty-eight hours later, the medium was removed, the cells were washed once with $10 \mathrm{ml}$ PBS, and labeling medium [4.5 ml DMEM, $0.5 \mathrm{ml}$ heat-inactivated, dialyzed FBS, $50 \mu \mathrm{l}$ penicillin-streptomycin solution, and $20 \mu \mathrm{l}$ $(\sim 230 \mu \mathrm{Ci})\left[{ }^{35} \mathrm{~S}\right]$ cysteine $]$ was added. The cells were incubated
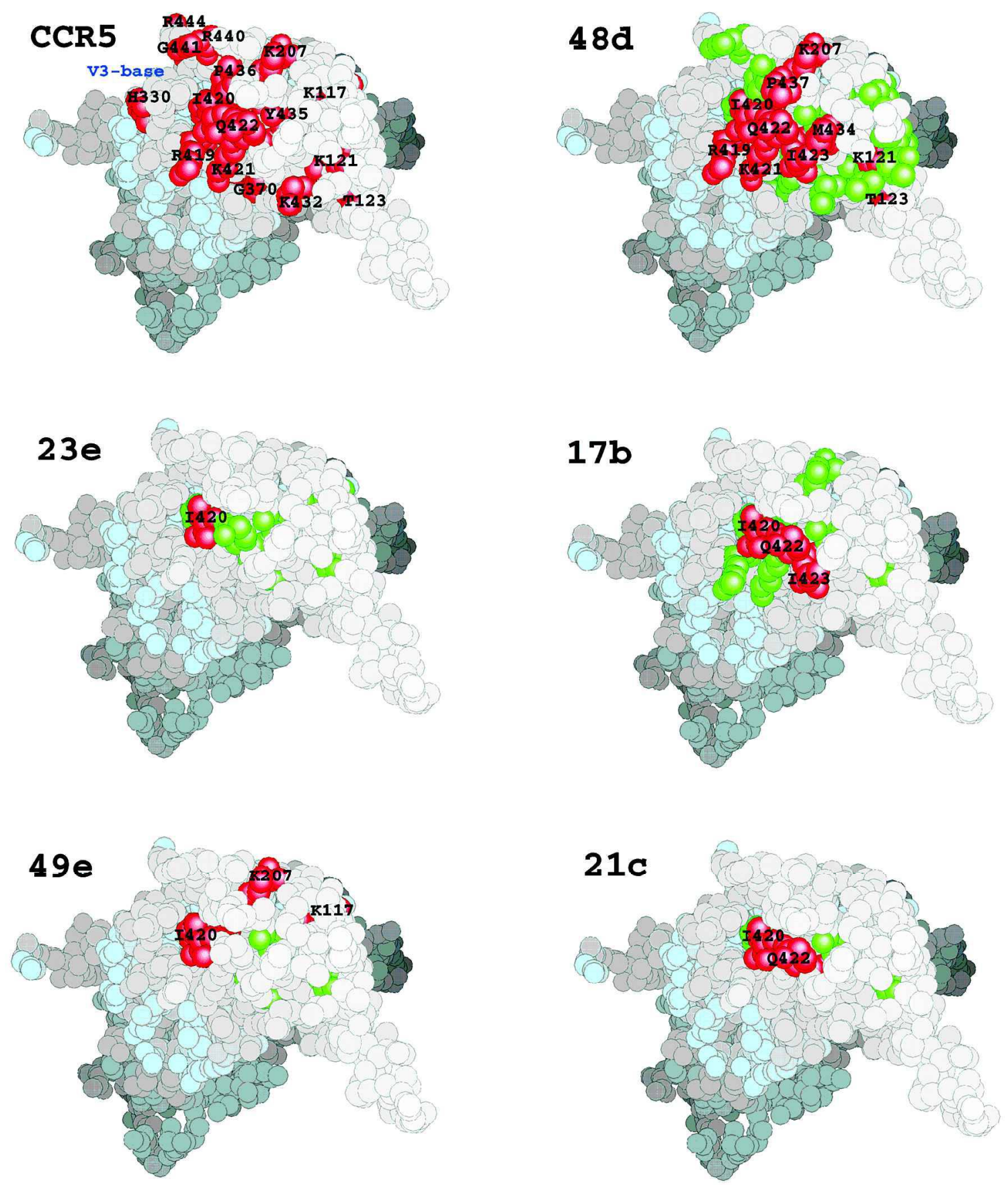

FIG. 3. (A-F) HIV-1 gp120 structures implicated in CCR5 and CD4i-HMAb binding. A CPK model of the HIV-1 YU2 gp120, derived from the ternary gp120-CD4-17b complex, ${ }^{28}$ is shown from the perspective of the target cell. Amino acid residues in which changes reduce the binding of ligands by $70 \%$ or more are colored. The residues in green indicate that ligand binding was restored by $\mathrm{sCD} 4$ binding. Changes in the residues colored red resulted in decreased ligand binding that was not restored by sCD4. The red residues are labeled with the residue number corresponding to that of the prototypic HXBc2 sequence. ${ }^{45}$ The residues important for CCR5 and $17 \mathrm{~b}$ binding were previously defined by Rizzuto et al. a $^{23}, 24$ 
at $37^{\circ} \mathrm{C}$ for $24 \mathrm{hr}$ and the medium was collected. The medium was cleared by centrifugation and stored at $4^{\circ} \mathrm{C}$.

\section{Immunoprecipitation of radiolabelled envelope glycoproteins}

For precipitation of radiolabeled HIV-1 envelope glycoproteins, $400 \mu \mathrm{l}$ medium containing the labeled proteins was mixed with $100 \mu \mathrm{l}$ of $10 \%$ protein A-Sepharose (Pharmacia), $50 \mu \mathrm{l}$ $4 \%$ bovine serum albumin, and either $1-2 \mu \mathrm{g}$ HMAb or $4 \mu \mathrm{l}$ of a mixture of HIV-1-infected sera. PBS was added to bring the total volume to $1 \mathrm{ml}$. The samples were rocked at $4{ }^{\circ} \mathrm{C}$ overnight or at room temperature for $2 \mathrm{hr}$. The Sepharose beads were then washed twice with $1 \mathrm{ml} 0.5 \mathrm{M} \mathrm{NaCl}$ in PBS and once with $1 \mathrm{ml}$ PBS. The beads were mixed with $2 \times$ gel loading buffer and boiled for 3 min. Following the removal of the beads by centrifugation, the supernatants were loaded on a $10 \%$ SDS-polyacrylamide gel. The gel was enhanced with Autofluor (National Diagnostic) for $45 \mathrm{~min}$ before drying at $80^{\circ} \mathrm{C}$ for 2 hr and exposure to film. The gel was also used for PhosphorImager (Molecular Dynamics) analysis.

\section{HIV-1 neutralization assay}

The HIV-1-neutralizing ability of the HMAbs was tested using a single-round virus entry assay. Recombinant HIV-1 ex-

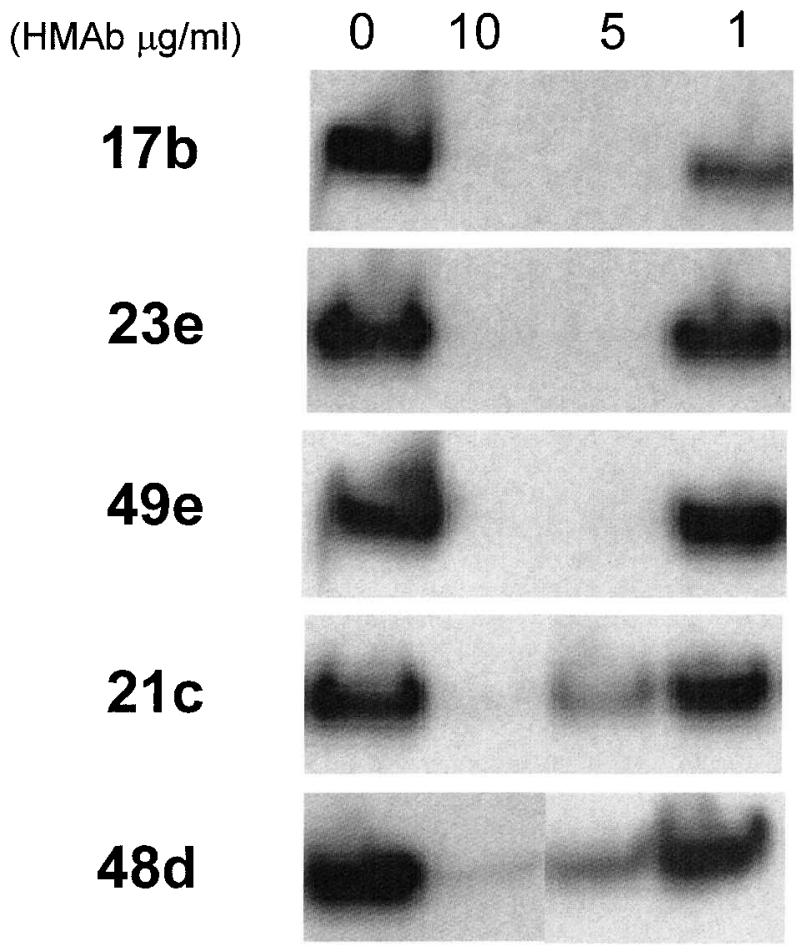

FIG. 4. Ability of CD4i HMAbs to inhibit gp120-CCR5 binding. Radiolabeled gp120 was mixed with sCD4 and then incubated with Cf2ThsynCCR5 cells in the presence of the indicated concentrations of CD4i HMAbs. The cells were washed and the bound gp120 was precipitated as described under Materials and Methods. The gp120 glycoprotein bound to the cells is shown. pressing the firefly luciferase gene was produced by transfecting $293 \mathrm{~T}$ cells with the pCMV Gag-Pol packaging construct and the pHIV-luc vector, along with a pSVIIIenv plasmid expressing the envelope glycoproteins of different HIV-1 strains. $^{20}$ Two days after transfection, the cell supernatants were harvested and frozen in aliquots.

The target cells (either Cf2Th cells expressing CD4 and CCR5 or Ghost cells expressing CD4 and CXCR4) were seeded at a density of $10^{5}$ cells/well in a 24-well plate and cultured overnight at $37^{\circ} \mathrm{C}$. From 10,000 to 30,00 reverse transciptase units of virus was incubated with serial dilutions of antibody for $1 \mathrm{hr}$ at $37^{\circ} \mathrm{C}$ in a $500 \mu \mathrm{l}$ volume. The target cells were washed once with PBS and the virus-antibody mixture was added to the cells. The cells were cultured for 3 days, washed once with PBS, and lysed with $150 \mu$ l lysis buffer for the luciferase assay (Tuner 20, Promega).

\section{RESULTS}

Effects of CD4 binding on HMAb recognition of gp120

The effects of soluble CD4 (sCD4) binding on the recognition of the HIV-1 gp120 glycoprotein by the newly identified HMAbs 23e, 49e, and 21c were examined. The wild-type gp 120 glycoprotein derived from the YU2 R5 HIV-1 strain was captured on an ELISA plate with a polyclonal serum (D7324) directed against the gp120 C-terminus. The captured gp120 was incubated with the HMAbs in the absence or presence of sCD4. Figure 1 shows that the recognition of the YU2 gp120 glycoprotein by the $23 \mathrm{e}, 49 \mathrm{e}$, and $21 \mathrm{c}$ antibodies was increased by sCD4. Soluble CD4 also increased the binding of the previously characterized $17 \mathrm{~b}$ and $48 \mathrm{~d} \mathrm{CD} 4 \mathrm{i}$ antibodies to gp120, as expected. ${ }^{30,38}$

\section{Ability of CD4i HMAbs to compete with $17 \mathrm{~b}$ antibody for gp 120}

To examine whether the newly identified CD4i HMAbs would compete with the previously characterized HMAb $17 \mathrm{~b}$ for binding to the HIV-1 gp120 glycoprotein, increasing concentrations of the CD4i HMAbs and a control antibody $2 / 11 \mathrm{C}$ were mixed with biotinylated $17 \mathrm{~b}$ antibody and incubated with the gp120 glycoprotein captured on an ELISA plate with the D7324 antibody. ${ }^{30}$ After washing, the bound biotinylated $17 \mathrm{~b}$ antibody was detected. All of the CD4i HMAbs competed with the $17 \mathrm{~b}$ antibody for gp120 binding (Fig. 2). The control antibody, $2 / 11 \mathrm{C}$, which recognizes a gp120 epitope that does not overlap with the CD4i epitopes, ${ }^{30}$ did not compete with the $17 \mathrm{~b}$ antibody (data not shown). This result suggests that all of the CD4i HMAbs recognize related gp120 regions.

\section{Mapping the gp120 epitopes of the CD4i HMAbs}

To characterize the CD4i antibody epitopes, a panel of YU2 wt $\Delta$ gp120 mutants with single amino acid changes was used for precipitation by the HMAbs, in the absence of sCD4. Mutant gp120 wt $\Delta$ glycoproteins that were recognized signifi- 
cantly less efficiently than the wild-type gp120 were also examined in the presence of sCD4. The wt $\Delta$ glycoprotein is identical to gp120 except for deletions of the N-terminus and V1/V2 variable loops. These deletions were previously demonstrated not to affect the binding of CD4 and CD4i antibodies. $^{24}$ The results are summarized in Table 1 . Changes in amino acids located in several discontinuous gp120 regions $(\mathrm{C} 1, \mathrm{C} 2, \mathrm{C} 3$, and $\mathrm{C} 4)$ resulted in decreased recognition by one or more of the HMAbs. In some cases, sCD4 binding to the mutant gp120 restored recognition by the HMAb. This subset of gp120 mutants probably exhibits local conformational changes that disrupt the particular HMAb epitope, and sCD4 binding restores the native conformation of the epitope. Some gp120 mutants that were able to bind sCD4 were not precipitated by the HMAbs in either the absence or presence of sCD4. These mutants are probably altered in amino acid residues that play key roles in antibody binding. Figure 3 illustrates the location of the amino acid changes that affected HMAb recognition, using the structure of the YU2 gp120 core complexed with two-domain CD4 and the Fab fragment of the $17 \mathrm{~b}$ antibody. ${ }^{28}$ The results suggest that the CD4i HMAbs recognize different gp120 epitopes that share a common element near isoleucine 420 . This common element also appears to be important for CCR5 binding. ${ }^{33,34}$ The $48 \mathrm{~d}$ antibody most closely resembles CCR5 with respect to its sensitivity to gp1 20 changes. The binding of both 48d and CCR5 was disrupted by more gp120 residue changes than was the binding of the $17 \mathrm{~b}, 23 \mathrm{e}, 49 \mathrm{e}$, and $21 \mathrm{c}$ antibodies.

\section{Ability of CD4i HMAbs to block CCR5 binding}

The mapping studies described above suggest that the epitopes for all of the CD4i HMAbs are proximal to conserved gp120 elements involved in CCR5 binding. To test the ability of the CD4i HMAbs to inhibit gp120-CCR5 binding, radiolabeled gp120 complexed with sCD4 was added to Cf2ThsynCCR5 cells, which express high levels of CCR5, ${ }^{12}$ in the presence of different concentrations of HMAbs. Figure 4 shows that all of the CD4i HMAbs inhibited the binding of gp120-sCD4 complexes to CCR5-expressing cells.

\section{CD4 and CD4i HMAbs recognize related gp120 conformations}

A few of the gp120 amino acid changes studied disrupted the binding of CD4 and most of the CD4i HMAbs. Examples of such mutants are 257 T/D, 383 F/S, and 435 Y/S. Previous studies $^{24}$ noted that the recognition of the $257 \mathrm{~T} / \mathrm{D}$ and $383 \mathrm{~F} / \mathrm{S}$ mutants by a conformation-dependent CD4BS HMAb, F105, was undetectable. The disruption of the binding of several conformation-dependent gp120 ligands and the low solvent accessibility of these residues in the available gp120 crystal structures $^{28,29}$ suggest that these changes significantly alter the conformation of the free gp120 glycoprotein. Figure 5A shows that although sCD4 and the 48d HMAb alone did not efficiently precipitate these mutant gp 120 glycoproteins, a combination of sCD4 and 48d did recognize the gp120 mutants. A similar result was observed for the 257 T/D gp120 mutant with the other CD4i HMAbs (Fig. 5B). These observations suggest that CD4 and the CD4i HMAbs recognize a similar gp120 conformation and therefore can mutually cooperate to allow precipitation of a conformationally disrupted gp120 variant.

\section{HIV-1-neutralizing activity of CD4i HMAbs}

To examine the ability of the CD4i HMAbs to inhibit HIV1 infection, we employed recombinant HIV-1 encoding fire-

\section{(A)}

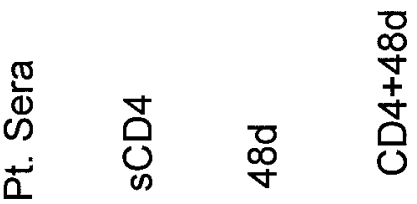

257 T/D

\section{$383 \mathrm{~F} / \mathrm{S}$}

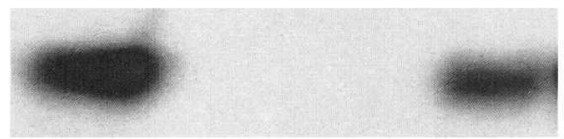

\section{$435 \mathrm{Y} / \mathrm{S}$}

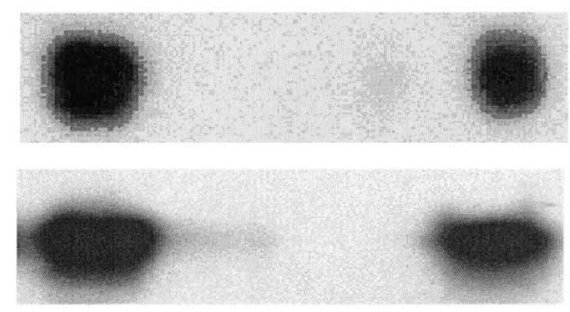

(B)

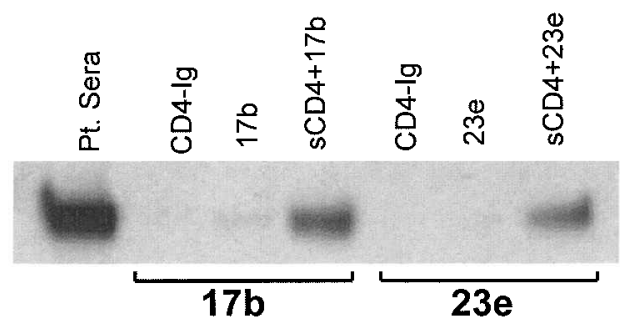

$257 \mathrm{~T} / \mathrm{D}$

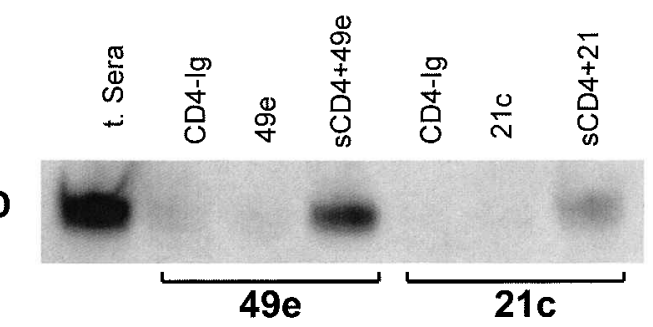

FIG. 5. Soluble CD4 and CD4i HMAbs exhibit positive cooperativity in precipitating HIV-1 gp120 glycoprotein mutants. (A) HIV-1 YU2 gp120 mutants that exhibit evidence of conformational disruption were radiolabeled and precipitated by a mixture of sera from HIV-1-infected individuals (Pt. Sera), sCD4, the 48d antibody, or a mixture of sCD4 and the 48d antibody. In the experiments in which sCD4 was added, the anti-CD4 polyclonal antibody T45 was included to allow precipitation of the sCD4-gp120 complex. The precipitated protein was analyzed by SDS-PAGE and autoradiography. (B) The radiolabeled 257 T/D mutant was precipitated by CD4-Ig, 17b, or a combination of sCD4 and 17b. The 257 T/D mutant was also precipitated by a mixture of sera from HIV-1-infected individuals (Pt. sera). The precipitated protein was analyzed by SDS-PAGE and autoradiography. 
fly luciferase pseudotyped with the envelope glycoproteins of laboratory-adapted and primary HIV-1 isolates. Ghost cells expressing CD4 and CXCR4 were used as target cells for viruses with the $\mathrm{X} 4 \mathrm{HXBc} 2$ and $\mathrm{MN}$ envelope glycoproteins and the X4/R5 89.6 envelope glycoproteins. Cf2Th cells expressing CD4 and CCR5 were used as target cells for viruses with the R5 ADA, JR-FL and YU2 envelope glycoproteins. Figure 6 shows that the viruses with the laboratory-adapted $\mathrm{HXBc} 2$ and $\mathrm{MN}$ envelope glycoproteins were neutralized comparably by all of the CD4i HMAbs. Of the viruses with primary HIV-1 envelope glycoproteins, the ADA virus but not JR-FL, 89.6, or YU2 was neutralized at the HMAb concentrations studied. Thus, primary HIV-1 isolates are more resistant to neutralization by the CD4i HMAbs than laboratory-adapted isolates.

\section{DISCUSSION}

The CD4-binding site (CD4BS) antibodies and the CD4i antibodies generated in HIV-1-infected humans are directed against overlapping, conserved, and conformation-dependent gp120 structures implicated in virus binding to CD4 and the chemokine receptors. ${ }^{28}$ Numerous examples of CD4BS HMAbs exist, allowing identification of the common elements of the $\mathrm{HMAb}$ epitopes and an appreciation of the range of neutralization potencies for primary HIV-1 isolates exhibited by this group of antibodies. Until recently, CD4i antibodies were thought to be rare, as only two such HMAbs, $17 \mathrm{~b}$ and $48 \mathrm{~d}$, existed. The apparent rarity of these antibodies has been attributed to the relative inaccessibility of the CD4i epitope on gp120..$^{22,39}$ In this report, we have identified three additional

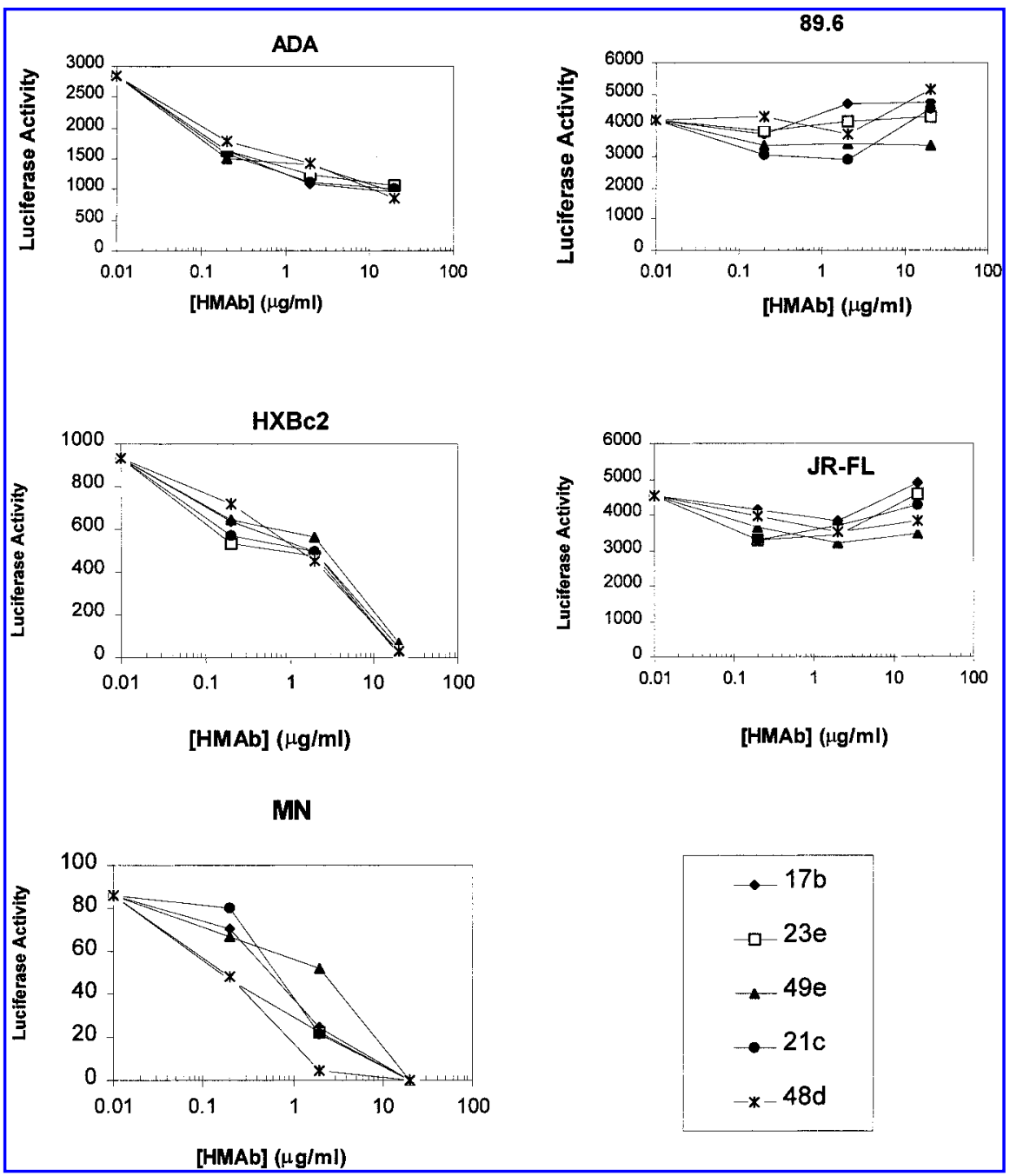

FIG. 6. Neutralization of HIV-1 by CD4i HMAbs. Recombinant HIV-1 expressing luciferase and containng env deletions were pseudotyped with HIV-1 envelope glycoproteins from the $\mathrm{HXBc} 2, \mathrm{MN}$, ADA, JR-FL, and 89.6 isolates. The viruses were incubated with the indicated concentration of HMAb for $1 \mathrm{hr}$ at $37^{\circ} \mathrm{C}$ prior to exposure to the appropriate target cells. Luciferase activity in the target cells was measured as described under Materials and Methods. 
CD4i HMAbs derived from an asymptomatic HIV-1-infected, long-term nonprogressorindividual(AD19). In addition, we derived another two CD4i HMAbs from later samples of PBMC of this same patient, and studies to further characterize these HMAbs are in progress. We were unable to derive CD4i HMAbs from six other long-term nonprogressor patients, suggesting that patient AD19 exhibited an unusually high frequency of circulating B cells capable of yielding such HMAbs.

The identification of the three new CD4i HMAbs allowed generalizations to be made regarding the structural characteristics of the epitope(s) that these antibodies recognize. The mutagenic data support the notion that all of the CD4i HMAbs recognize similar structures on a conserved portion of the gp120 surface that is thought to face the target cell after CD4 binding occurs. The epitopes for all of the CD4i HMAbs appear to be centered around a sequence in the fourth conserved (C4) gp120 region at the junction of the $\beta 19$ and $\beta 20$ strands. The critical residues 418-422 (CRIKQ) are highly conserved in primate immunodeficiency virus gp120 glycoproteins and have been implicated in binding the N-terminus of the CCR5 receptor. ${ }^{48,49}$ Consistent with this, all of the CD4i HMAbs blocked the binding of gp120-CD4 complexes to CCR5. The importance of a localized gp120 region for the binding of all of the CD4i HMAbs examined suggests that only limited patches of conserved sequence on the gp 120 chemokine receptor-binding surface are available to be accessed by antibodies. This limitation is thought to be imposed by the V2 and V3 variable loops, which project from the gp 120 core and are thought to flank the conserved chemokine receptor-binding region, partially mask-

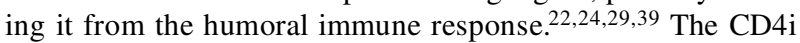
HMAbs apparently have evolved to contact conserved gp120 epitopes in this region and bypass the adjacent variable loops.

Based on thermodynamic studies, ${ }^{50} \mathrm{CD} 4$ binding has been suggested to limit an unusually high degree of interdomain flexibility present in the free HIV-1 gp120 glycoprotein. Because the conserved CD4i epitope component (residues 418-422) is located at the interface of the gp120 outer domain and bridging sheet, ${ }^{28,29}$ ligands like CD4 that modify the spatial relationships among the gp120 domains would be expected to influence the conformation of the CD4i epitopes. The ability of CD4i antibodies and sCD4 to mutually induce binding to gp120 glycoprotein variants that exhibit conformational perturbations (Fig. 5) suggests that these ligands recognize related gp120 conformations.

Although the CD4i HMAbs contact a conserved gp120 element, changes in the major gp120 variable loops can influence the binding of these HMAbs. Removal of the V1/V2 loop has been shown to expose the epitopes for some CD4i HMAbs. ${ }^{22}$ At least some of CD4-induced increase in CD4i HMAb binding can be attributed to movement of the V1/V2 loops from a position that masks the CD4i epitopes. The deletion of the V3 variable loop from the wt $\Delta$ protein resulted in a loss of recognition by the CD4i HMAbs, unless sCD4 was present. ${ }^{23}$ Most of this effect is probably an indirect consequence of V3 loop removal on the local conformation of the gp120 bridging sheet. However, current structures on the gp120-17b antibody complexes leave open the possibility of V3 loop-antibody contacts. $^{28,29}$ The relatively efficient binding of the CD4i antibodies to V3 loop-deleted gp120 in the presence of CD4 suggests that such contacts, if they occur, contribute minimal binding energy to the antibody-gp120 interaction.

The results of our virus inhibition studies indicate a remarkable similarity in the potency and breadth of neutralization exhibited by the different CD4i HMAbs. This may result from the close relatedness of the epitopes for these HMAbs imposed by the gp120 variable structures discussed above. Differences in the conformations of the V2 and V3 variable loops have been shown to account for at least some of the neutralization resistance associated with primary compared with laboratory-adapted strains of HIV $-1 .{ }^{40}$ Such differences in V2 and V3 loop configurations provide a natural explanation for the limited sensitivity of primary HIV-1 isolates to neutralization by CD4i HMAbs. One primary isolate, ADA, exhibited some sensitivity to the CD4i HMAbs. Possibly relevant is our observation that removal of the V1/V2 variable loops renders the ADA HIV-1 isolate CD4 independent, ${ }^{51}$ suggesting that the ADA CCR5-binding region is either formed or can be formed without prior CD4 binding. Likewise, the CD4i epitopes on the ADA gp120 glycoprotein may be available for antibody binding once the V2 loop is bypassed. As the neutralization potency of CD4i antibodies depends on their ability to bind the viral envelope glycoproteins prior to CD4 binding, ${ }^{20}$ a virus that has the CD4i epitope preformed in the absence of CD4 would be more sensitive to neutralization by these antibodies. More neutralization-resistant viruses might employ both V2 loop masking and conformational flexibility of CD4i epitope components to minimize the efficacy of CD4i antibodies. Further understanding of these epitopes and the mehcanisms employed by HIV-1 to protect them from the neutralizing antibody response may suggest strategies for intervention in virus transmission or spread within the host.

\section{ACKNOWLEDGMENTS}

This study was supported by grants from the National Institutes of Health (AI24755, AI31783, AI41851, AI46725, and AI24030), by a Center for AIDS Research grant (AI42848), and by gifts from the G. Harold and Leila Y. Mathers Charitable Foundation, the Friends 10, the late William F. McCartyCooper, and Douglas and Judith Krupp. S.-H. Xiang was supported by an Australian National Health and Medical Research Council HIV/AIDS fellowship (987185).

\section{REFERENCES}

1. Barre-Sinossi F, Chermann F, Rey MT, et al.: Isolation of a T-lymphotropic retrovirus from a patient at risk for acquired immunodeficiency syndrome (AIDS). Science 1983;220:868-871.

2. Gallo RC, Salahuddin SZ, Popovic M, et al:: Frequent detection and isolation of cytopathic retroviruses (HTLV-III) from patients with AIDS and at risk for AIDS. Science 1984;224:500-503.

3. Cicala C, Arthos J, Rubbert A, et al.: HIV-1 envelope induces activation of caspase- 3 and cleavage of focal adhesion kinase in primary human CD4(+) $\mathrm{T}$ cells. Proc Natl Acad Sci USA 2000;97(3):1178-1183.

4. Fauci AS: The human immunodeficiency virus: Infectivity and mechanisms of pathogenesis. Science 1988;239(4840):617-622. 
5. Fauci AS: Immunopathogenesis of HIV infection. J Acquir Immune Defic Syndr 1993;6(6):655-662.

6. Gougeon ML, Garcia S, Heeney J, et al.: Programmed cell death in AIDS-related HIV and SIV infections. AIDS Res Hum Retroviruses 1993;9(6):553-563.

7. Gougeon ML, Montagnier L: Programmed cell death as a mechanism of CD4 and CD8 T cell deletion in AIDS. Molecular control and effect of highly active anti-retroviral therapy. Ann NY Acad Sci 1999;887:199-212.

8. Rosenberg ZF and Fauci AS: Immunopathogenetic mechanisms of HIV infection. Clin Immunol Immunopathol 1989;50(1 Pt. 2): S149-156.

9. Dalgleish AG, Beverley PC, Clapham PR, Crawford DH, Greaves MF, and Weiss RA: The CD4 (T4) antigen is an essential component of the receptor for the AIDS retrovirus. Nature 1984;312(5996):763-767.

10. Deng H, Liu R, Ellmeier W, et al.: Identification of a major co-receptor for primary isolates of HIV-1. Nature 1996;381(6584): 661-666.

11. Klatzmann D, Champagne E, Chamaret S, et al:: T-lymphocyte T4 molecule behaves as the receptor for human retrovirus LAV. Nature 1984;312:767-768.

12. Mirzabekov T, Bannert N, Farzan M, et al.: Enhanced expression, native purification, and characterization of CCR5, a principal HIV1 coreceptor. J Biol Chem 1999;274(40):28745-28750.

13. Blacklow SC, Lu M, and Kim PS: A trimeric subdomain of the simian immunodeficiency virus envelope glycoprotein. Biochemistry 1995;34(46):14955-14962.

14. Bleul CC, Farzan M, Choe H, et al.: The lymphocyte chemoattractant SDF-1 is a ligand for LESTR/fusin and blocks HIV-1 entry. Nature 1996;382(6594):829-833.

15. Choe H, Farzan M, Sun Y, et al.: The beta-chemokine receptors CCR3 and CCR5 facilitate infection by primary HIV-1 isolates. Cell 1996;85(7):1135-1148.

16. Choe H, Martin KA, Farzan M, Sodroski J, Gerard NP, and Gerard C. Structural interactions between chemokine receptors, gp120 Env and CD4. Semin Immunol 1998;10(3):249-257.

17. Deichmann M, Kronenwett R, and Haas R: Expression of the human immunodeficiency virus type-1 coreceptors CXCR-4 (fusin, LESTR) and CKR-5 in CD4+ hematopoietic progenitor cells. Blood 1997;89(10):3522-3528.

18. Delezay O, Koch N, Yahi N, et al.: Co-expression of CXCR4/fusin and galactosylceramide in the human intestinal epithelial cell line HT-29. AIDS 1997;11(11):1311-1318.

19. Sodroski J, Wyatt R, Olshevsky U, Olshevsky V, and Moore J. Conformation of the HIV-1 gp120 envelope glycoprotein. Antibiot Chemother 1996;48:184-187.

20. Sullivan N, Sun Y, Sattentau Q, et al.: CD4-Induced conformational changes in the human immunodeficiency virus type $1 \mathrm{gp} 120$ glycoprotein: Consequences for virus entry and neutralization. J Virol 1998;72(6):4694-4703.

21. Wyatt R, Kwong PD, Desjardins E, et al.: The antigenic structure of the HIV gp120 envelope glycoprotein. Nature 1998;393(6686): 705-711.

22. Wyatt R, Moore J, Accola M, Desjardin E, Robinson J, and Sodroski J. Involvement of the V1/V2 variable loop structure in the exposure of human immunodeficiency virus type 1 gp120 epitopes induced by receptor binding. J Virol 1995;69(9):5723-5733.

23. Rizzuto $\mathrm{C}$ and Sodroski J. Fine definition of a conserved CCR5binding region on the human immunodeficiency virus type 1 glycoprotein 120. AIDS Res Hum Retroviruses 2000;16(8):741-749.

24. Rizzuto CD, Wyatt R, Hernandez-Ramos N, et al.: A conserved HIV gp120 glycoprotein structure involved in chemokine receptor binding. Science 1998;280(5371):1949-1953.

25. Thali M, Furman C, Wahren B, et al.: Cooperativity of neutraliz- ing antibodies directed against the V3 and CD4 binding regions of the human immunodeficiency virus gp120 envelope glycoprotein. J Acquir Immune Defic Syndr 1992;5(6):591-599.

26. Ye Y, Si ZH, Moore JP, and Sodroski J: Association of structural changes in the V2 and V3 loops of the gp120 envelope glycoprotein with acquisition of neutralization resistance in a simian-human immunodeficiency virus passaged in vivo. J Virol 2000;74(24): 11955-11962.

27. Zhang W, Canziani G, Plugariu C, et al.: Conformational changes of gp120 in epitopes near the CCR5 binding site are induced by CD4 and a CD4 miniprotein mimetic. Biochemistry 1999;38(29): 9405-9416.

28. Kwong PD, Wyatt R, Majeed S, et al.: Structures of HIV-1 gp120 envelope glycoproteins from laboratory-adapted and primary isolates. Struct Fold Des 2000;8(12):1329-1339.

29. Kwong PD, Wyatt R, Robinson J, Sweet RW, Sodroski J, and Hendrickson WA. Structure of an HIV gp120 envelope glycoprotein in complex with the CD4 receptor and a neutralizing human antibody. Nature 1998;393(6686):648-659.

30. Moore JP and Sodroski J: Antibody cross-competition analysis of the human immunodeficiency virus type 1 gp120 exterior envelope glycoprotein. J Virol 1996;70(3):1863-1872.

31. Chan DC, Fass D, Berger JM, and Kim PS: Core structure of gp41 from the HIV envelope glycoprotein. Cell 1997;89(2):263-273.

32. Kim EM, Lee KH, and Kim JW: The cytoplasmic domain of HIV$1 \mathrm{gp} 41$ interacts with the carboxyl-terminal region of alpha-catenin. Mol Cells 1999;9(3):281-285.

33. Finzi D and Siliciano RF: Viral dynamics in HIV-1 infection. Cell 1998;93(5):665-671.

34. Siliciano JD and Siliciano RF: Latency and viral persistence in HIV-1 infection. J Clin Invest 2000;106(7):823-825.

35. Wyatt R and Sodroski J: The HIV-1 envelope glycoproteins: Fusogens, antigens, and immunogens. Science 1998;280(5371): 1884-1888.

36. Binley JM, Wyatt R, Desjardins E, et al.: Analysis of the interaction of antibodies with a conserved enzymatically deglycosylated core of the HIV type 1 envelope glycoprotein 120. AIDS Res Hum Retroviruses 1998;14(3):191-198.

37. Thali M, Charles M, Furman C, et al.: Resistance to neutralization by broadly reactive antibodies to the human immunodeficiency virus type 1 gp120 glycoprotein conferred by a gp41 amino acid change. J Virol 1994;68(2):674-680.

38. Thali M, Moore JP, Furman C, et al.: Characterization of conserved human immunodeficiency virus type $1 \mathrm{gp} 120$ neutralization epitopes exposed upon gp120-CD4 binding. J Virol 1993;67(7): 3978-3988.

39. Cao J, Sullivan N, Desjardin E, et al:: Replication and neutralization of human immunodeficiency virus type 1 lacking the V1 and V2 variable loops of the gp120 envelope glycoprotein. J Virol 1997;71(12):9808-9812.

40. Sullivan N, Sun Y, Binley J, et al.: Determinants of human immunodeficiency virus type 1 envelope glycoprotein activation by soluble CD4 and monoclonal antibodies. J Virol 1998;72(8): 6332-6338.

41. Sullivan N, Thali M, Furman C, Ho DD, and Sodroski J: Effect of amino acid changes in the V1/V2 region of the human immunodeficiency virus type $1 \mathrm{gp} 120$ glycoprotein on subunit association, syncytium formation, and recognition by a neutralizing antibody. J Virol 1993;67(6):3674-3679.

42. Thali M, Olshevsky U, Furman C, Gabuzda D, Li J, and Sodroski $\mathrm{J}$ : Effects of changes in gp120-CD4 binding affinity on human immunodeficiency virus type 1 envelope glycoprotein function and soluble CD4 sensitivity. J Virol 1991;65(9):5007-5012.

43. Thali M, Olshevsky U, Furman C, Gabuzda D, Posner M, and Sodroski J: Characterization of a discontinuous human immunodefi- 
ciency virus type 1 gp120 epitope recognized by a broadly reactive neutralizing human monoclonal antibody. J Virol 1991;65 (11):6188-6193.

44. Wu L, Gerard NP, Wyatt R, et al.: CD4-induced interaction of primary HIV-1 gp120 glycoproteins with the chemokine receptor CCR-5. Nature 1996;384(6605):179-83.

45. Korber B, Foley F, Kuiken C, Pillai S, and Sodroski J: Numbering positions in HIV relative to $\mathrm{HXBc2}$. In: B. Korber, C. Kuiken, B. Foley, B. Hahn, F. McCutchen, J. Mellors, and J. Sodroski (eds.) Human Retroviruses and AIDS 1998. Los Alamos, NM: Los Alamos Laboratory, 1998.

46. Robinson JE, Cole KS, Elliott DH, et al:: Production and characterization of SIV envelope-specific rhesus monoclonal antibodies from a macaque asymptomatically infected with a live SIV vaccine. AIDS Res Hum Retroviruses 1998;14(14):1253-1262.

47. Robinson JE, Holton D, Liu J, McMurdo H, Murciano A, and Gohd R: A novel enzyme-linked immunosorbent assay (ELISA) for the detection of antibodies to HIV-1 envelope glycoproteins based on immobilization of viral glycoproteins in microtiter wells coated with concanavalin. J Immunol Methods 1990;132:63-71.

48. Dragic T, Trkola A, Lin SW, et al.: Amino-terminal substitutions in the CCR5 coreceptor impair gp120 binding and human immunodeficiency virus type 1 entry. J Virol 1998;72(1):279-285.
49. Farzan M, Vasilieva N, Schnitzler CE, et al.: A tyrosine-sulfated peptide based on the $\mathrm{N}$ terminus of CCR5 interacts with a CD4enhanced epitope of the HIV-1 gp120 envelope glycoprotein and inhibits HIV-1 entry. J Biol Chem 2000;275(43):33516-21.

50. Myszka DG, Sweet RW, Hensley P, et al.: Energetics of the HIV gp120-CD4 binding reaction. Proc Natl Acad Sci USA 2000; 97(16):9026-9031.

51. Kolchinsky P, Kiprilov E, Bartley P, Rubinstein R, and Sodroski $\mathrm{J}$ : Loss of a single N-linked glycan allows CD4-independent human immunodeficiency virus type 1 infection by altering the position of the gp120 V1/V2 variable loops. J Virol 2001;75(7): 3435-3443.

Address reprint requests to: James E. Robinson Department of Pediatrics Tulane University Medical Center 1430 Tulane Avenue New Orleans, LA 70012

E-mail: jrobinso@tulane.edu 


\section{This article has been cited by:}

1. Aemro Kassa, Zohar Biron-Sorek, Pampi Sarkar, Indresh K. SrivastavaDesigning Immunogens for Vaccine Development in Reference to HIV 141-184. [CrossRef]

2. Weizao Chen, Xiaodong Xiao, Yanping Wang, Zhongyu Zhu, Dimiter S. Dimitrov. 2010. Bifunctional fusion proteins of the human engineered antibody domain m36 with human soluble CD4 are potent inhibitors of diverse HIV-1 isolates. Antiviral Research 88:1, 107-115. [CrossRef]

3. Qigui Yu, Richard Yu, Xuebin Qin. 2010. The good and evil of complement activation in HIV-1 infection. Cellular and Molecular Immunology 7:5, 334-340. [CrossRef]

4. Barton F Haynes, Nathan I Nicely, S Munir Alam. 2010. HIV-1 autoreactive antibodies: are they good or bad for HIV-1 prevention?. Nature Structural \& Molecular Biology 17:5, 543-545. [CrossRef]

5. Ron Diskin, Paola M Marcovecchio, Pamela J Bjorkman. 2010. Structure of a clade C HIV-1 gp120 bound to CD4 and CD4-induced antibody reveals anti-CD4 polyreactivity. Nature Structural \& Molecular Biology 17:5, 608-613. [CrossRef]

6. X. Shen, S. M. Dennison, P. Liu, F. Gao, F. Jaeger, D. C. Montefiori, L. Verkoczy, B. F. Haynes, S. M. Alam, G. D. Tomaras. 2010. Prolonged exposure of the HIV-1 gp41 membrane proximal region with L669S substitution. Proceedings of the National Academy of Sciences 107:13, 5972-5977. [CrossRef]

7. John R. Mascola, David C. Montefiori. 2010. The Role of Antibodies in HIV Vaccines. Annual Review of Immunology 28:1, 413-444. [CrossRef]

8. Stephanie Planque, Maria Salas, Yukie Mitsuda, Marcin Sienczyk, Miguel A Escobar, Jason P Mooney, Mary-Kate Morris, Yasuhiro Nishiyama, Dipanjan Ghosh, Amit Kumar, Feng Gao, Carl V Hanson, Sudhir Paul. 2010. Neutralization of genetically diverse HIV-1 strains by IgA antibodies to the gp120 CD4-binding site from long-term survivors of HIV infection. AIDS 24:6, 875-884. [CrossRef]

9. Françoise Baleux, Latino Loureiro-Morais, Yael Hersant, Pascal Clayette, Fernando ArenzanaSeisdedos, David Bonnaffé, Hugues Lortat-Jacob. 2009. A synthetic CD4-heparan sulfate glycoconjugate inhibits CCR5 and CXCR4 HIV-1 attachment and entry. Nature Chemical Biology 5:10, 743-748. [CrossRef]

10. Smita S. Kulkarni, Alan Lapedes, Haili Tang, S. Gnanakaran, Marcus G. Daniels, Ming Zhang, Tanmoy Bhattacharya, Ming Li, Victoria R. Polonis, Francine E. McCutchan, Lynn Morris, Dennis Ellenberger, Salvatore T. Butera, Robert C. Bollinger, Bette T. Korber, Ramesh S. Paranjape, David C. Montefiori. 2009. Highly complex neutralization determinants on a monophyletic lineage of newly transmitted subtype C HIV-1 Env clones from India. Virology 385:2, 505-520. [CrossRef]

11. Emma T. Crooks, Pengfei Jiang, Michael Franti, Sharon Wong, Michael B. Zwick, James A. Hoxie, James E. Robinson, Penny L. Moore, James M. Binley. 2008. Relationship of HIV-1 and SIV envelope glycoprotein trimer occupation and neutralization. Virology 377:2, 364-378. [CrossRef]

12. Leo Heyndrickx, Tine Vermoesen, Katleen Vereecken, Julia Kurth, Sandra Coppens, Laetitia Aerts, Asa Ohagen, Yven Van Herrewege, Paul Lewi, Guido Vanham. 2008. Antiviral compounds show enhanced activity in HIV-1 single cycle pseudovirus assays as compared to classical PBMC assays. Journal of Virological Methods 148:1-2, 166-173. [CrossRef]

13. A. DeVico, T. Fouts, G. K. Lewis, R. C. Gallo, K. Godfrey, M. Charurat, I. Harris, L. Galmin, R. Pal. 2007. Antibodies to CD4-induced sites in HIV gp120 correlate with the control of SHIV challenge in macaques vaccinated with subunit immunogens. Proceedings of the National Academy of Sciences 104:44, 17477-17482. [CrossRef]

14. M. Huber, A. Trkola. 2007. Humoral immunity to HIV-1: neutralization and beyond. Journal of Internal Medicine 262:1, 5-25. [CrossRef]

15. John R. Vu , Timothy Fouts, Katherine Bobb , Jennifer Burns , Brenda McDermott, David I. Israel , Karla Godfrey , Anthony DeVico . 2006. An Immunoglobulin Fusion Protein Based on the gp120-CD4 Receptor Complex Potently Inhibits Human Immunodeficiency Virus Type 1 in VitroAn Immunoglobulin Fusion Protein Based on the gp120-CD4 Receptor Complex Potently Inhibits Human 
Immunodeficiency Virus Type 1 in Vitro. AIDS Research and Human Retroviruses 22:6, 477-490. [Abstract] [PDF] [PDF Plus]

16. Ralph Pantophlet, Dennis R. Burton. 2006. GP120: Target for Neutralizing HIV-1 Antibodies. Annual Review of Immunology 24:1, 739-769. [CrossRef]

17. Nigel J. Dimmock. 2005. The complex antigenicity of a small external region of theC-terminal tail of the HIV-1 gp41 envelope protein: a lesson in epitope analysis. Reviews in Medical Virology 15:6, 365-381. [CrossRef]

18. Michael Tuen, Maria Luisa Visciano, Peter C. Chien, Sandra Cohen, Pei-de Chen, James Robinson, Yuxian He, Abraham Pinter, Miroslaw K. Gorny, Catarina E. Hioe. 2005. Characterization of antibodies that inhibit HIV gp120 antigen processing and presentation. European Journal of Immunology 35:9, 2541-2551. [CrossRef]

19. Alain Mechulam, Martine Cerutti, Martine Pugnière, Dorothée Missé, Johanna Gajardo, Françoise Roquet, James Robinson, Francisco Veas. 2005. Highly conserved \#16/\#17 \#-hairpin structure in human immunodeficiency virus type 1 YU2 gp120 is critical for CCR5 binding. Journal of Molecular Medicine 83:7, 542-552. [CrossRef]

20. R MEYUHAS, H NOY, D MONTEFIORI, G DENISOVA, J GERSHONI, G GROSS. 2005. HIV-1 neutralization by chimeric CD4-CG10 polypeptides fused to human IgG1. Molecular Immunology 42:9, 1099-1109. [CrossRef]

21. Wen Yuan, Stewart Craig, Xinzhen Yang, Joseph Sodroski. 2005. Inter-subunit disulfide bonds in soluble HIV-1 envelope glycoprotein trimers. Virology 332:1, 369-383. [CrossRef]

22. Indresh K Srivastava, Jeffrey B Ulmer, Susan W Barnett. 2004. Neutralizing antibody responses to HIV: role in protective immunity and challenges for vaccine design. Expert Review of Vaccines 3:4s1, S33-S52. [CrossRef]

23. Susan Zolla-Pazner. 2004. Identifying epitopes of HIV-1 that induce protective antibodies. Nature Reviews Immunology 4:3, 199-210. [CrossRef]

24. Hyeryun Choe, Wenhui Li, Paulette L. Wright, Natalya Vasilieva, Miro Venturi, Chih-Chin Huang, Christoph Grundner, Tatyana Dorfman, Michael B. Zwick, Liping Wang, Eric S. Rosenberg, Peter D. Kwong, Dennis R. Burton, James E. Robinson, Joseph G. Sodroski, Michael Farzan. 2003. Tyrosine Sulfation of Human Antibodies Contributes to Recognition of the CCR5 Binding Region of HIV-1 gp120. Cell 114:2, 161-170. [CrossRef]

25. Nancy L Haigwood, Leonidas Stamatatos. 2003. Role of neutralizing antibodies in HIV infection. AIDS 17:Supplement 4, 67-71. [CrossRef] 